\title{
Harvesting the Future Crop ${ }^{1}$
}

by

\author{
G.V. Wellburn ${ }^{2}$
}

\section{Introduction}

I was pleased to be asked to talk to you about "Harvesting the Future Crop" because it is of interest to me and has given me an opportunity to discuss it with many people. I hope those of you from other parts of Canada will forgive me if I talk mostly about the Coast. It is the area with the biggest difference between the old growth and second growth and harvesting the second crop has begun. This paper is divided into three parts: timber supply, logging machines and systems, and institutional and administrative constraints.

\section{Timber Supply}

To get a broad picture of the timber inventory, I contacted the Vancouver Ministry of Forests Regional Manager and the chief foresters of the major Coast companies. I used two areas - south Coast, which includes most of Vancouver Island and southern mainland, and north Coast, which includes the Nootka Public Sustained Yield Unit (PSYU). The timber was classified as either old growth or second growth. Table 1 shows the cut in 1985, 1995, and forecast for the year 2085 100 years from now. No one who replied anticipated much of a reduction in the cut or a shift from the south to north Coast.It is interesting that more old growth will be cut in 2085 than we are cutting second growth today.

As you can see, we are now cutting $4.7 \%$ second growth. This has increased rapidly in the past 5 years and will continue to rise. By the year 1995 , it will be up to $11.5 \%$ of the cut and, in the Quadra PSYU and on parts of Vancouver Island and the Fraser Valley, it will be up to $30 \%$.

These numbers confirm that we have a timber supply, we are following a sustained yield policy, and we are moving into second growth. Now let's consider economics. A recent study by Williams and Gasson of FEPA ${ }^{3}$ states that only $26 \%$ of the mature timber on the Coast is economically assessible (see Figure 1). Dr. Peter Pearse used this study to recommend that the allowable cuts should be reduced. Before we accept a reduction, we should look closely at the study. As Patrick Durrant of the province pointed out on August 3, a slight margin between profit and loss applies to a great deal of the inventory and that an increase in value or reduction in cost would make $80 \%$ of the timber accessible rather than only $26 \%$.

1 Paper given at the Logging Working Group Technical Session, at the Annual Meeting of the CIF in Victoria, B.C.. September 1986

2Vice-President and General Manager, Western Division, Forest Engineering Research Institute of Canada, 201-2112 West Broadway, Vancouver, B.C. V6K $2 \mathrm{CB}$.

${ }^{3}$ Forest Economic Policy Analysis Project at the University of British Columbia.
Secondly, the study uses the Vancouver log market to determine value. This is reasonable for the sawing portion but not reasonable for the pulp log portion. The pulp and paper mills receive their wood supply from their own operations and from purchased chips. They do not need or want additional pulp logs, therefore, the market price is low. This price does not represent the true value of these logs or the cost of the pulp logs from company operations. The economics of logging on the Coast are certainly tight and we must reduce costs and increase the value if we are to log the majority of the timber inventory.

\section{Logging Machines and Methods}

Harvesting the second crop is exciting. Most of the merchantable second growth is on good ground accessible to mills and towns. Logging methods already in use in the Interior and other parts of Canada can be adapted. Feller-bunchers will be used extensively for safer felling and to bunch trees for both skidding and yarding. Several companies have experimented with feller bunchers. Antler Creek Logging, of Port Alberni, have built a special heavy-duty west Coast buncher and Weldco of Vancouver are making machines that will operate on $40 \%$ slopes. The Rotosaw, made by Risely Equipment in Grand Prairie, Alberta, works well on trees up to 28 inches and there is a wide variety of smaller felling heads. Grapple skidders with either standard or wide tires skidding to roadside or to processors produce the lowest cost. The Coast is fortunate to have yarding cranes (grapple yarders) which are required for old growth logging. These machines are often available in the winter and can be used to log second growth from sensitive sites or slopes. Our studies show that grapple yarding bunches is almost as cheap as ground skidding.

New developments in limbing and bucking processors are now taking place. Stroke and slide boom delimbers have been used in the east and interior pine. These are now being equipped with measuring devices and bucking saws. The Hahn processor has been used successfully in many areas. The Weyerhaeuser Steyr processor is used at roadside and Spruce City Hydraulics, a Company in Prince George, is working on a similar machine. FERIC is working on a processor attachment for a coast loader that will permit it to limb, buck, sort and load long logs from windrows. The Ranger-Kockums machines use methods developed in Sweden. they process at the stump and deliver fully manufactured short logs to roadside. This system will have applications on some sites, particularly where logs are shipped to different specialty mills. 


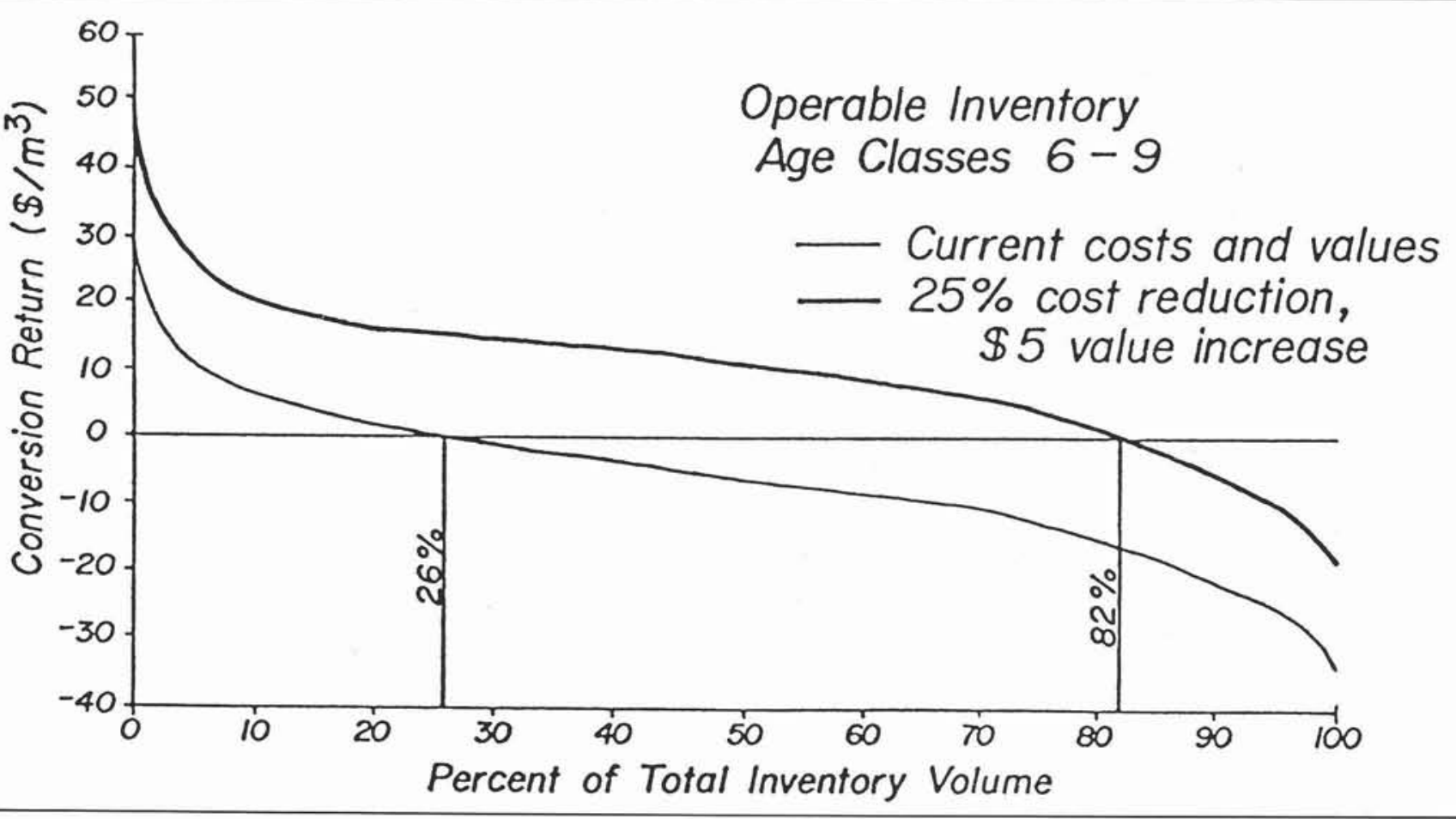

Figure 1. Distribution of decreasing conversion return for the coastal timber supply areas

\begin{tabular}{|c|c|c|c|c|c|c|}
\hline & \multicolumn{2}{|c|}{1985} & \multicolumn{2}{|c|}{1995} & \multicolumn{2}{|c|}{2085} \\
\hline & old gr. & 2nd gr. & old gr. & 2nd gr. & old gr. & 2nd gr. \\
\hline $\begin{array}{l}\text { South Coast } \\
\text { North Coast } \\
\text { Total }\end{array}$ & $\begin{array}{r}19945 \\
5468 \\
25413\end{array}$ & $\begin{array}{r}1160 \\
115 \\
1275\end{array}$ & $\begin{array}{r}17415 \\
5431 \\
22846\end{array}$ & $\begin{array}{r}2805 \\
160 \\
2965\end{array}$ & $\begin{array}{l}2186 \\
1701 \\
3887\end{array}$ & $\begin{array}{r}17359 \\
2890 \\
20249\end{array}$ \\
\hline $\begin{array}{l}\text { Total Cut } \\
\% \text { 2nd Growth } \\
\% \text { North Coast }\end{array}$ & \multicolumn{2}{|c|}{$\begin{array}{c}26688 \\
4.7 \\
20.9\end{array}$} & \multicolumn{2}{|c|}{$\begin{array}{l}25811 \\
11.5 \\
21.7\end{array}$} & \multicolumn{2}{|c|}{$\begin{array}{c}24136 \\
83.8 \\
19.0\end{array}$} \\
\hline
\end{tabular}

NOTE: - Estimates from companies and Ministry of Forests

- Totals do not include all Companies or owners.

These new machines and others not yet off the drawing board will harvest the new crop efficiently. The hauling distances will be short because much of the new forest is close to mills and the costs should be similar to Interior costs.

The low value of second-growth logs is a concern. The stands are high quality but this is not reflected in the price. Oldgrowth hemlock and cedar sells for $\$ 50 / \mathrm{m}^{3}$ but beautiful young Douglas-fir is only worth $\$ 35 / \mathrm{m}^{3}$. Part of the reason for this is that the mills have not had a sufficient volume to saw and market it separately. We hope that the new specialty mills, like the new Whonnock "Linch" mill, will improve sawing techniques. Also that the Douglas-fir task force and work done at FORINTEK will provide buyers with better information on the characteristics of the new crop.

Before I leave machines and systems, I should mention commercial thinning. The key word is "commercial". It's an economic problem, not a technical problem. Selective cutting will always cost more than clearcutting and leaving the best trees reduces the value of the first harvest. Until prices rise or some of the cost is charged to forest management, I do not see much future for thinning

\section{Administrative and Institutional Constraints}

Now let's look at the administrative and institutional constraints.

I think that resistance to change is the greatest problem that we face in the transition from the old to new forest. The lack of flexible policies of companies, governments, associations, and unions is threatening our very survival. The recent IWA strike clearly illustrates that we do not know how to cope with change. It is regrettable that contracting became an issue because second-growth logging offers many opportunities for small entrepreneurs.

A major difference between the Coast and the Interior is that in the Interior senior managers from the companies, union, forest service and agencies are close to the operations. When specific problems arise, all the individuals concerned get together and work out practical common-sense solutions. On the Coast, a specific problem is referred to head offices which in turn may refer it to associations, such as the Council of Forest Industries or Forest Industrial Relations. People who are not directly involved try to relate the problem to a general policy. The result is antagonism between union and labour, or 
industry and agency, and companies are forced to waste money following general rules rather than concentrating their effort on specific problems.

Let me give you an example. In the early 1970s, loggers all over the province were under pressure from the public and environmental agencies to change logging practices. Ground skidding, in particular, was considered harmful. In the Interior, where ground skidding accounted for more than $95 \%$ of the logging, the Ministry considered banning it on slopes of over $50 \%$. On the Coast, where ground skidding had traditionally been about $20 \%$ of the cut, the Ministry introduced the Coast guidelines which restricted many logging practices.

In the Interior, after a great deal of complaining, the companies and Ministry set up working committees, such as the steep slope committee. These committees invited the Canadian Forestry Service to conduct a study to determine the severity of the problem. They invited FERIC to recommend alternative systems and evaluate new methods. The Ministry of Forests itself conducted an experiment in long distance yarding. They even wrote a handbook on ground skidding. As a result, skidding practices were improved, new methods such as small cats were introduced, and the more expensive cable logging was confined to the most extreme sites. Most importantly, they developed a working relationship between government and industry to solve specific problems.

On the Coast, the reaction was passive. A COFI committee was set up and ground skidding was simply banned. No studies were conducted to determine the seriousness of the problem or evaluate alternatives. Ground skidding reduces cost by at least $\$ 3 / \mathrm{m}^{3}$. Think how much

\section{ASSISTANT PROFESSOR WODC WHYSICS}

The Department of Harvesting and Wood Science requires an individual with teaching and research experience in the field of Wood Physics, including knowledge of wood-liquid relationships and the transport processes affecting the movement of liquids in wood products during drying and treating processes.

Duties: The position requires teaching of undergraduate and graduate courses, direction of graduate research and development of a wood physics research program.

Qualifications: Ph.D. in Wood Science and Technology or a Ph.D. in a similar program which provides the candidate with a broad background knowledge of wood (wood anatomy, wood mechanics, wood chemistry) and its processing, and a detailed knowledge of thermodynamics and transport processes in wood products. Research and teaching experience in wood physics is required Superior writing and speaking skills are necessary.

Salary: Commensurate with qualifications and experience.

Position: Assistant Professor (tenure track) appointment to be effective Aug 1, 1987 subject to budgetary approval.

Applications: Curriculum vitae and names of three professional references should be forwarded to:

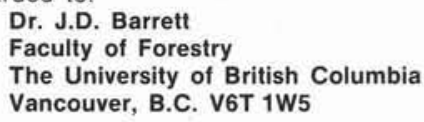

Application closing date is June 15, 1987

In accordance with Canadian Immigration requirements, this advertisement is directed to Canadian citizens and permanent residents. money we could have saved in the past 15 years if we had used it where acceptable.

So what, you may say - this is history - but is it? Many companies are now being threatened with fines for site degredation and many interior foresters are raging. The coast is passive. Wake up this time, its not just a matter of higher costs but whether we can harvest the second crop. If we are going to log the new crop cost-efficiently, we must use fellerbunchers and skidders and the most cost effective methods. Studies that measure and document site disturbance are needed so that we can intelligently specify logging methods. FERIC is working with the ministry and MacMillan Bloedel to set up a study at Port Alberni.

The problems of logging the second crop and the remaining first crop are not technical but economic. One way to improve the results is to eliminate the losers. As a start, why don't we set up a system to review all cutting permits that show a significant loss on appraisal. Instead of just accepting the loss, we should see whether something can be done to reduce it. Perhaps logging should be deferred, different machines used, or the utilization standard changed, or the boundaries of the cutting area changed, or something done to increase the value. FERIC is working with FEPA and UBC to provide specific information for this type of analysis.

I am optimistic but concerned about logging the second crop. We have high site lands, a well-managed forest, a skilled and ingenious work force, and modern mills. I am sure that we can solve our technical problems. The question is, "Do we have the will to work together to make it all happen?" Can we get our act together? I think we can - but it's up to you.

\section{Woodlot Service (1978) Ltd.}

"All Matters Pertaining to Forestry"

\section{GORDON B. YOUNG, B.Sc.F., M.F. Registered Professional Forester}

320 Maple Street

Fredericton, N.B.

Bus.: 506-458-9366

E3A 3B4 